Provided for non-commercial research and education use. Not for reproduction, distribution or commercial use.

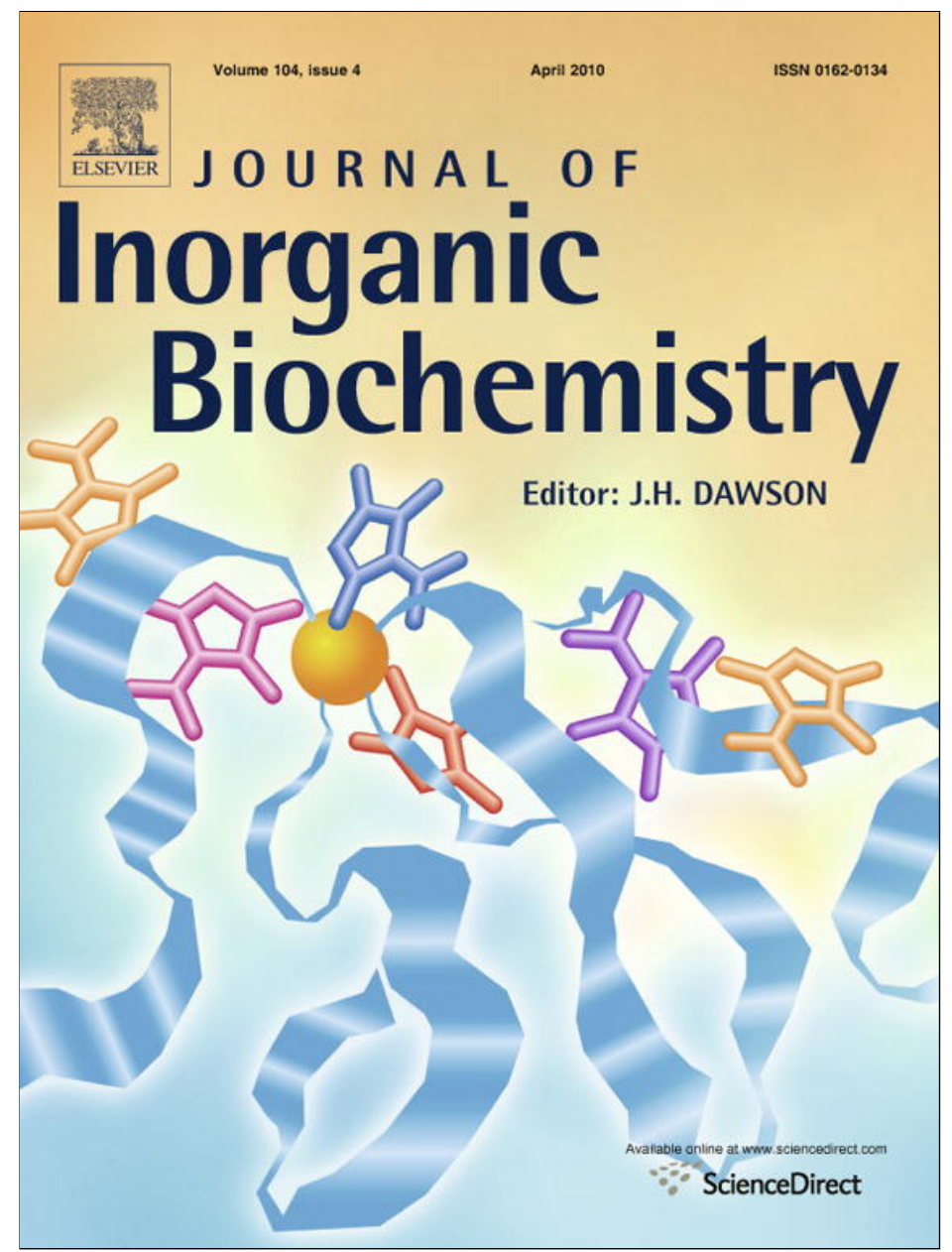

This article appeared in a journal published by Elsevier. The attached copy is furnished to the author for internal non-commercial research and education use, including for instruction at the authors institution and sharing with colleagues.

Other uses, including reproduction and distribution, or selling or licensing copies, or posting to personal, institutional or third party websites are prohibited.

In most cases authors are permitted to post their version of the article (e.g. in Word or Tex form) to their personal website or institutional repository. Authors requiring further information regarding Elsevier's archiving and manuscript policies are encouraged to visit:

http://www.elsevier.com/copyright 


\title{
Synthesis, crystal structure, characterization of zinc(II), cadmium(II) complexes with 3-thiophene aldehyde thiosemicarbazone (3TTSCH). Biological activities of 3TTSCH and its complexes
}

\author{
Kusaï Alomar ${ }^{\mathrm{a}}$, Anne Landreau ${ }^{\mathrm{a}}$, Marie Kempf ${ }^{\mathrm{b}}$, Mustayeen A. Khan ${ }^{\mathrm{a}}$, Magali Allain ${ }^{\mathrm{c}}$, Gilles Bouet ${ }^{\mathrm{a}, *}$ \\ a Laboratoire SONAS, EA 921, IFR QUASAV 149, Université d'Angers, UFR Sciences Pharmaceutiques et Ingénierie de la Santé, 16 Boulevard Daviers, 49045 Angers cedex 01, France \\ ${ }^{\mathrm{b}}$ Laboratoire de Bactériologie, CHU d'Angers, 4 rue Larrey, 49933 Angers cedex 9, France \\ ' Laboratoire de Chimie, Ingénierie Moléculaire d'Angers (CIMA), UMR CNRS 6200 - Université d'Angers, 2, Boulevard Lavoisier, 49045 Angers cedex, France
}

\section{A R T I C L E I N F O}

\section{Article history:}

Received 31 July 2009

Received in revised form 20 November 2009

Accepted 21 November 2009

Available online 3 December 2009

\section{Keywords:}

Thiosemicarbazone

3-thiophene aldehyde

Crystal structure

Metal complexes

Biological activity

\begin{abstract}
A B S T R A C T
The reaction of zinc(II) chloride, cadmium(II) chloride and bromide with 3-thiophene aldehyde thiosemicarbazone leads to the formation of a series of new complexes. They have been characterized by spectroscopic studies: infrared, ${ }^{1} \mathrm{H}$ NMR, and electronic spectra. The crystal structures of the compound $\left[\mathrm{ZnCl}_{2}(3 \mathrm{TTSCH})_{2}\right]$ and $\left[\mathrm{CdBr}_{2}(3 \mathrm{TTSCH})_{2}\right]$ have been determined by X-ray diffraction methods. For the complexes $\left[\mathrm{ZnCl}_{2}(3 \mathrm{TTSCH})_{2}\right]$ and $\left[\mathrm{CdBr}_{2}(3 \mathrm{TTSCH})_{2}\right]$, the central ion is coordinated through the sulfur, and for the complexes $\left[\mathrm{CdCl}_{2}(3 T T S C H)\right],\left[\mathrm{CdBr}_{2}(3 T T S C H)\right]$ the ion is coordinated through the sulfur as well as azomethine nitrogen atom of the thiosemicarbazone. In addition, fungistatic and bacteriostatic activities of both ligand and complexes have been evaluated. Cadmium(II) complexes have shown the most significant activities.
\end{abstract}

(c) 2009 Elsevier Inc. All rights reserved.

\section{Introduction}

Thiosemicarbazones and their metal complexes have become the subject of intensive study because of their wide ranging biological activities, analytical applications and interesting chemical and structural properties. The structural diversity of thiosemicarbazide-based compounds is considerably increased not only due to the condensation of the different carbonyls but also due to the alkylation of the different parts of the thiosemicarbazide moiety [1].

The complexes of metals of column 12 constitute an especially attractive topic in view of the marked differences among these metals as regards both chemical behavior and biological activity. $\mathrm{Zn}(\mathrm{II})$ is an essential ion because of its presence in certain metalloenzymes while cadmium and mercury, present in the environment, are toxic but only recent studies have considered the reactivity of macroligands containing sulfur with zinc, cadmium and mercury [2].

The biological activity and the medicinal properties of thiosemicarbazones depend upon the chemical nature of the moiety attached to the $\mathrm{C}=\mathrm{S}$ carbon atom. Zinc atom has either a structural or catalytic role in several proteins [3]. It has been recognized as an important cofactor in biological molecules, either as a structural

\footnotetext{
* Corresponding author. Tel.: +332412266 00; fax: +33241226634

E-mail address: gilles.bouet@univ-angers.fr (G. Bouet).
}

template in protein folding or as a Lewis acid catalyst that can readily adopt 4-, 5- or 6-coordination [4].

Cadmium is an extremely toxic element which is often present in the environment and also as a result of human activities. Its toxicity derives from the fact that it is rapidly localized intracellularly, mainly in the liver, and then is bound to metallothionein forming a complex that is slowly transferred to the bloodstream to be deposited in the kidneys. Therefore, it is an interesting area of research to get compounds which are able to form stable complexes with cadmium, because they could be employed as detoxificating agents. For this purpose, thiosemicarbazone ligands could be very appropriate as both the ligands and their complexes have shown a wide range of pharmacological properties. In particular, cadmium and mercury complexes of the related ligand benzyl bis(thiosemicarbazone) have antimicrobial and antifungal activities, so it could be expected that these cadmium derivatives also possess some activity and studies are underway [5].

Thiosemicarbazones and their derivatives have antifungal activity. N(4)-tolyl-2-benzoylpyridine thiosemicarbazones and their copper(II) complexes were tested as antifungal on Candida albicans [6]. 5-Methyl-2-furfural thiosemicarbazone and its nickel and copper complexes were used as antifungal against on Aspergillus fumigatus and C. albicans [7].

As a part of our continuous research work pertaining to the synthesis and biological activity of metal complexes from semicarbazones [8,9] and thiosemicarbazones from 2-furaldehyde [7,10], 
we describe here some new transition metal complexes obtained from 3-thiophenaldehyde thiosemicarbazone (3TTSCH) (Fig. 1) as ligand. We have previously reported the crystal structure of the ligand and described the complexes deriving from nickel(II), cobal$\mathrm{t}(\mathrm{II})$ and copper(II) [11]. The nickel(II) complex [Ni(3TTSC) $)_{2}$, as well as the cobalt(II) complex [Co(3TTSC $\left.)_{2}\right]$, coordinates via the thiol deprotonated tautomer though $\mathrm{S}$ (thione) and $\mathrm{N}$ (azomethine) atoms. In the case of copper(II), three species were obtained: $\left[\mathrm{CuBr}_{2}(3 \mathrm{TTSCH})\right]$ is a mononuclear species (thione tautomer, $\mathrm{S}$ and $\mathrm{N}$ imino as coordinating atoms) while $[\mathrm{CuCl}(3 \mathrm{TTSC})]_{2}$ and $[\mathrm{CuBr}(3 \mathrm{TTSC})]_{2}$ are binuclear complexes (thiol deprotonated tautomer, $\mathrm{S}$ and $\mathrm{N}$ imino as coordinating atoms). We report here new complexes prepared with zinc(II) chloride, and cadmium(II) chloride or bromide. In addition, the crystal structures of $\left[\mathrm{ZnCl}_{2}(3 \mathrm{TTSCH})_{2}\right]$ and of $\left[\mathrm{CdBr}_{2}(3 \mathrm{TTSCH})_{2}\right]$ are described. Finally, the ligand and all the complexes were tested as fungicidal and bacteriostatic compounds.

\section{Experimental}

\subsection{Reactants}

All reactants and solvents were analytical grade. Thiosemicarbazide, thiophene-3-carboxaldehyde and anhydrous zinc chloride were purchased from Alfa Aesar. Cadmium chloride and bromide salts (Prolabo) were used as received.

\subsection{Measurements}

Elemental analyses were carried out by the service central of analyses (C.N.R.S. Vernaison, France). The ${ }^{1} \mathrm{H}$ NMR spectra were recorded on a Jeol GSX WB spectrometer at $270 \mathrm{MHz}$ in DMSO- $\mathrm{D}_{6}$, the chemical shifts are given in ppm, using TMS as internal reference. DSC diagrams were recorded in the $25-400^{\circ} \mathrm{C}$ range with a Mettler DSC $822^{\mathrm{e}}$ unit, with the help of Mettler Toledo STAR ${ }^{\mathrm{e}}$ SW 8.10 System software (Laboratoire de Physique, Faculté de Pharmacie, Angers); the heating rate was $10^{\circ} \mathrm{C} / \mathrm{min}$. All measurements were made in $40 \mathrm{~mm}^{3}$ closed $\mathrm{Al}$ crucibles. The IR spectra were recorded with a Bruker FTIR Vector 22 spectrometer between 4400 and $400 \mathrm{~cm}^{-1}$ (KBr disks).

\subsection{Crystal data collection and processing}

Crystals of $\left[\mathrm{ZnCl}_{2}(3 \mathrm{TTSCH})_{2}\right]$ and $\left[\mathrm{CdBr}_{2}(3 \mathrm{TTSCH})_{2}\right]$ are triclinic with space group $P-1$. The crystal and instrumental parameters used in the unit-cell determination and data collection are summarized in Tables 1 and 2. X-ray single-crystal diffraction data were collected at $293 \mathrm{~K}$ on a STOE-IPDS diffractometer, equipped with a graphite monochromator using Mo $K_{\alpha}$ radiation $(\lambda=0.71073 \AA)$ (CIMMA, UMR CNRS 6200, Université d'Angers). The structure was solved by direct methods and the refinement was performed on $F^{2}$ by full matrix least-squares techniques using SHELX-97 pack-

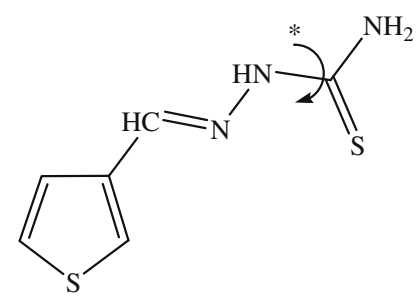

Fig. 1. Chemical structure of the ligand $3 \mathrm{TTSCH}$. ( ${ }^{*} 180^{\circ}$ bond rotation upon coordination).
Table 1

Crystallographic data.

\begin{tabular}{|c|c|c|}
\hline Formula & $\mathrm{C}_{12} \mathrm{H}_{14} \mathrm{Cl}_{2} \mathrm{ZnN}_{6} \mathrm{~S}_{4}$ & $\mathrm{C}_{12} \mathrm{H}_{14} \mathrm{Br}_{2} \mathrm{CdN}_{6} \mathrm{~S}_{4}$ \\
\hline Name & {$\left[\mathrm{ZnCl}_{2}(3 \mathrm{TTSCH})_{2}\right]$} & {$\left[\mathrm{CdBr}_{2}\left(3 \mathrm{TTSCH}_{2}\right]\right.$} \\
\hline Formula weight & 506.80 & 642.75 \\
\hline Crystal system & Triclinic & Triclinic \\
\hline Space group & $\mathrm{P}-1$ & $\mathrm{P}-1$ \\
\hline$a(\AA)$ & $7.758(1)$ & $8.0415(8)$ \\
\hline$b(\AA)$ & $9.793(1)$ & $9.776(1)$ \\
\hline$c(\AA)$ & $14.581(2)$ & $14.839(2)$ \\
\hline$\alpha\left({ }^{\circ}\right)$ & $80.06(2)$ & $79.61(1)$ \\
\hline$\beta\left(^{\circ}\right)$ & $75.65(2)$ & $74.61(1)$ \\
\hline$\gamma\left({ }^{\circ}\right)$ & $72.36(2)$ & $71.48(1)$ \\
\hline$V\left(\AA^{3}\right)$ & $1017.0(2)$ & $1060.6(2)$ \\
\hline$Z$ & 2 & 2 \\
\hline Color & Brown & Orange \\
\hline$D_{\text {calc }}\left(\mathrm{g} \mathrm{cm}^{-3}\right)$ & 1.655 & 2.013 \\
\hline$F\left(\begin{array}{lll}0 & 0 & 0\end{array}\right)$ & 512 & 620 \\
\hline Crystal size (mm) & $0.62 \times 0.46 \times 0.15$ & $0.54 \times 0.15 \times 0.15$ \\
\hline$\mu\left(\mathrm{mm}^{-1}\right)$ & 1.889 & 5.200 \\
\hline \multirow[t]{3}{*}{$h k l$ limits } & $-9 \leqslant h \leqslant 9$ & $-9 \leqslant h \leqslant 9$ \\
\hline & $-12 \leqslant k \leqslant 12$ & $-12 \leqslant k \leqslant 11$ \\
\hline & $-17 \leqslant l \leqslant 17$ & $-18 \leqslant l \leqslant 18$ \\
\hline$\theta_{\min }, \theta_{\max }\left({ }^{\circ}\right)$ & 2.26 & 2.26 \\
\hline Number of data with $I>2 \sigma(I)$ & $3067 F_{o}$ & $2987 F_{o}$ \\
\hline Number of variables & 283 & 282 \\
\hline$R 1$ & 0.0495 & 0.0444 \\
\hline$w R 2$ & 0.1400 & 0.0838 \\
\hline
\end{tabular}

Weighing scheme: $w=1 /\left[\sigma^{2}\left(F_{o}^{2}\right)+(0.1714 \mathrm{P})^{2}\right]$ with $P=\left(F_{o}^{2}+2 F_{c}^{2}\right) / 3$.

Table 2

Selected bond lengths $(\AA)$ and angles $\left(^{\circ}\right)$ for the zinc complex.

\begin{tabular}{llll}
\hline Bond lengths & & Bond angles & \\
\hline $\mathrm{C}(1)-\mathrm{N}(2)$ & $1.314(5)$ & $\mathrm{N}(2)-\mathrm{C}(1)-\mathrm{N}(1)$ & $119.3(4)$ \\
$\mathrm{C}(1)-\mathrm{N}(1)$ & $1.326(5)$ & $\mathrm{N}(2)-\mathrm{C}(1)-\mathrm{S}(1)$ & $120.9(3)$ \\
$\mathrm{C}(1)-\mathrm{S}(1)$ & $1.733(4)$ & $\mathrm{N}(1)-\mathrm{C}(1)-\mathrm{S}(1)$ & $119.8(3)$ \\
$\mathrm{C}(2)-\mathrm{N}(3)$ & $1.281(5)$ & $\mathrm{N}(3)-\mathrm{C}(2)-\mathrm{C}(3)$ & $121.6(4)$ \\
$\mathrm{N}(2)-\mathrm{N}(3)$ & $1.392(5)$ & $\mathrm{C}(1)-\mathrm{N}(2)-\mathrm{N}(3)$ & $119.7(3)$ \\
$\mathrm{S}(1)-\mathrm{Zn}(1)$ & $2.3690(11)$ & $\mathrm{C}(2)-\mathrm{N}(3)-\mathrm{N}(2)$ & $113.4(4)$ \\
$\mathrm{Cl}(1)-\mathrm{Zn}(1)$ & $2.2882(12)$ & $\mathrm{C}(1)-\mathrm{S}(1)-\mathrm{Zn}(1)$ & $103.23(13)$ \\
$\mathrm{Cl}(2)-\mathrm{Zn}(1)$ & $2.2737(12)$ & $\mathrm{C}(7)-\mathrm{S}(3)-\mathrm{Zn}(1)$ & $103.21(14)$ \\
& & $\mathrm{Cl}(2)-\mathrm{Zn}(1)-\mathrm{Cl}(1)$ & $110.90(5)$ \\
& & $\mathrm{Cl}(2)-\mathrm{Zn}(1)-\mathrm{S}(1)$ & $111.62(5)$ \\
& & $\mathrm{Cl}(1)-\mathrm{Zn}(1)-\mathrm{S}(1)$ & $108.93(4)$ \\
& & $\mathrm{Cl}(2)-\mathrm{Zn}(1)-\mathrm{S}(3)$ & $107.46(5)$ \\
& & $\mathrm{Cl}(1)-\mathrm{Zn}(1)-\mathrm{S}(3)$ & $110.12(5)$ \\
& & $\mathrm{S}(1)-\mathrm{Zn}(1)-\mathrm{S}(3)$ & $107.75(4)$ \\
\hline
\end{tabular}

age [12]. All non- $\mathrm{H}$ atoms were refined anisotropically and the $\mathrm{H}$ atoms were included in the calculation without refinement. Absorption was corrected by Gaussian technique.

\subsection{Synthesis of the ligand 3TTSCH}

The ligand was obtained from thiophene-3-carboxaldehyde and thiosemicarbazide (1:1 $\mathrm{M}$ ratio) in absolute ethanol with addition of two drops of sulfuric acid [13]. The mixture was refluxed for $1 \mathrm{~h}$ and then cooled. The solid which precipitated was filtered and recrystallized from ethanol.

\subsection{Preparation of the complexes}

All the complexes were prepared starting from $5 \mathrm{mmol}(1 \mathrm{~g})$ of 3TTSCH dissolved in EtOH. The ethanolic solution of the metal halide was added slowly while stirring. The complexes were removed by filtration, washed with $\mathrm{MeOH}$ and finally dried in vacuum over silica gel. 
2.5.1. Dichloro bis(3-thiophenaldehyde thiosemicarbazone) zinc(II) $\left[\mathrm{ZnCl}_{2}(3 \mathrm{TTSCH})_{2}\right]$

$\mathrm{ZnCl}_{2}$ (0.36 g; $\left.2.5 \mathrm{mmol} ; 10 \mathrm{~mL}\right)$ was added to the $3 \mathrm{TTSCH}(1 \mathrm{~g}$; $5 \mathrm{mmol} ; 15 \mathrm{~mL})$ ethanolic solution $(10 \mathrm{~mL})$ under refluxing condition. An aqueous solution of sodium hydroxide was added drop wise to reach $\mathrm{pH}$ in the range of 6-7. The reflux was maintained

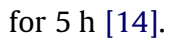

\subsubsection{Dichloro (3-thiophenaldehyde thiosemicarbazone) cadmium(II) $\left[\mathrm{CdCl}_{2}(3 \mathrm{TTSCH})\right]$}

3TTSCH $(1 \mathrm{~g} ; 5 \mathrm{mmol} ; 15 \mathrm{~mL})$ was mixed with $\mathrm{CdCl}_{2}(0.99 \mathrm{~g}$; $5 \mathrm{mmol}, 15 \mathrm{~mL})$. The complex precipitated during the addition of the metal salt, but to complete the reaction, the solution was refluxed for $1 \mathrm{~h}$.

\subsubsection{Dibromo (3-thiophenaldehyde thiosemicarbazone) cadmium(II) [CdBr 2 (3TTSCH)]}

$\mathrm{CdBr}_{2}(1.46 \mathrm{~g} ; 5 \mathrm{mmol}, 10 \mathrm{~mL})$ was added to the 3TTSCH $(1 \mathrm{~g}$; $5 \mathrm{mmol} ; 15 \mathrm{~mL}$ ) ethanolic at room temperature for $3 \mathrm{~h}$.

\subsubsection{Dibromo bis(3-thiophenaldehyde thiosemicarbazone) $\operatorname{cadmium}(\mathrm{II})\left[\mathrm{CdBr}_{2}(3 \mathrm{TTSCH})_{2}\right]$}

$\mathrm{CdBr}_{2}(0.73 \mathrm{~g} ; 2.5 \mathrm{mmol}, 10 \mathrm{~mL}$ ) was added to the $3 \mathrm{TTSCH}$ ( $1 \mathrm{~g}$; $5 \mathrm{mmol} ; 15 \mathrm{~mL}$ ) ethanolic under refluxing conditions. The reflux was maintained for $3 \mathrm{~h}$.

\subsection{Biological activities}

\subsubsection{Microorganisms}

Antifungal activity was assayed on human pathogenic fungi, including yeasts of the Candida genus: C. albicans (ATCC 66396), C. glabrata (LMA 90-1085), and one opportunistic mould A. fumigatus (CBS 11326). All fungi were obtained from the parasitology and mycology laboratory of the CHU of Angers. Moulds were cultivated at $37^{\circ} \mathrm{C}$ on yeast extract-peptone-dextrose agar (YPDA) containing $0.5 \mathrm{~g} \mathrm{~L}^{-1}$ chloramphenicol 2 days for yeasts and 3 days for A. fumigatus.

Bacteriostatic activity of complexes was evaluated on 21 bacterial strains obtained from the laboratory of bacteriology from the University Hospital of Angers: seven strains of A. baumannii (RCH, SAN008, 12, AYE, CIP7034, CIP107292, CIP5377), five of
Staphylococcus aureus (ATCC25923, 2 meticillin sensitive clinical isolates, two meticillin resistant clinical isolates), two of Escherichia coli (ATCC25922 and a clinical isolate), three of Pseudomonas aeruginosa (ATCC27853 and two clinical isolates), one clinical isolate of Enterobacter cloacae, of Enterobacter aerogenes, of Klebsiella oxytoca and of Salmonella enteritidis (phage type 4).

\subsubsection{Determination of antifungal activity}

Antifungal activity of the different compounds (ligands, metal salts and complexes) was evaluated using a disk diffusion method routinely used for yeasts [15], and adapted here for A. fumigatus. Briefly, compounds were dissolved in DMSO at a final concentration of $10 \mathrm{mg} / \mathrm{mL}$ and $25 \mu \mathrm{L}$ aliquots were applied on $12 \mathrm{~mm}$ diameter paper disks (rf 06234304, Prolabo 33173 Gradigan, France). After evaporating the solvent, disks were deposited in the center of $90 \mathrm{~mm}$ diameter Casitone agar plates previously flooded with $10 \mathrm{~mL}$ of spore suspensions. After the incubation time, the inoculum suspension was prepared for yeasts by suspending one colony in $10 \mathrm{~mL}$ of sterile distilled water. For the filamentous fungus, the mycelium was recovered by scraping the agar plates with $10 \mathrm{~mL}$ of sterile distilled water, conidia were then harvested by filtration through $25 \mu \mathrm{m}$ pore size nylon Monyl membranes and finally, absorbance of the filtrate at $630 \mathrm{~nm}$ was adjusted by spectrophotometry to 0.1 . Negative control was performed using filter papers soaked with an equal volume of respectively metal salts and drugfree solvent (DMSO), and positive controls were made with Neosensitabs tablets of Amphotericin B (Rosco Diagnostic, Taastrup, Denmark). After incubation, diameter of the growth inhibition zones ( $\mathrm{mm}$ ) was measured around the paper disks or Neosensitabs tablets.

\subsubsection{Determination of bacteriostatic activity}

Tests were performed using the methodology described in the guidelines of the Comité de l'Antibiogramme de la Société Française de Microbiologie (CA-SFM, www.sfm.asso.fr). Briefly, a stock solution of each compound was prepared at $20 \mathrm{mg} / \mathrm{mL}$ in DMSO under sterile conditions. Then, serial dilutions were performed and $100 \mu \mathrm{L}$ of each dilution were added in $19.9 \mathrm{~mL}$ Mueller Hinton agar (Merck Germany) and transferred into Petri plates. The concentrations of each compound tested were: 1, 10, 20, 30, 40, 50, 60,80 and $100 \mu \mathrm{g} / \mathrm{mL}$. Bacterial inoculum. About $2 \times 10^{4}$ bacteria

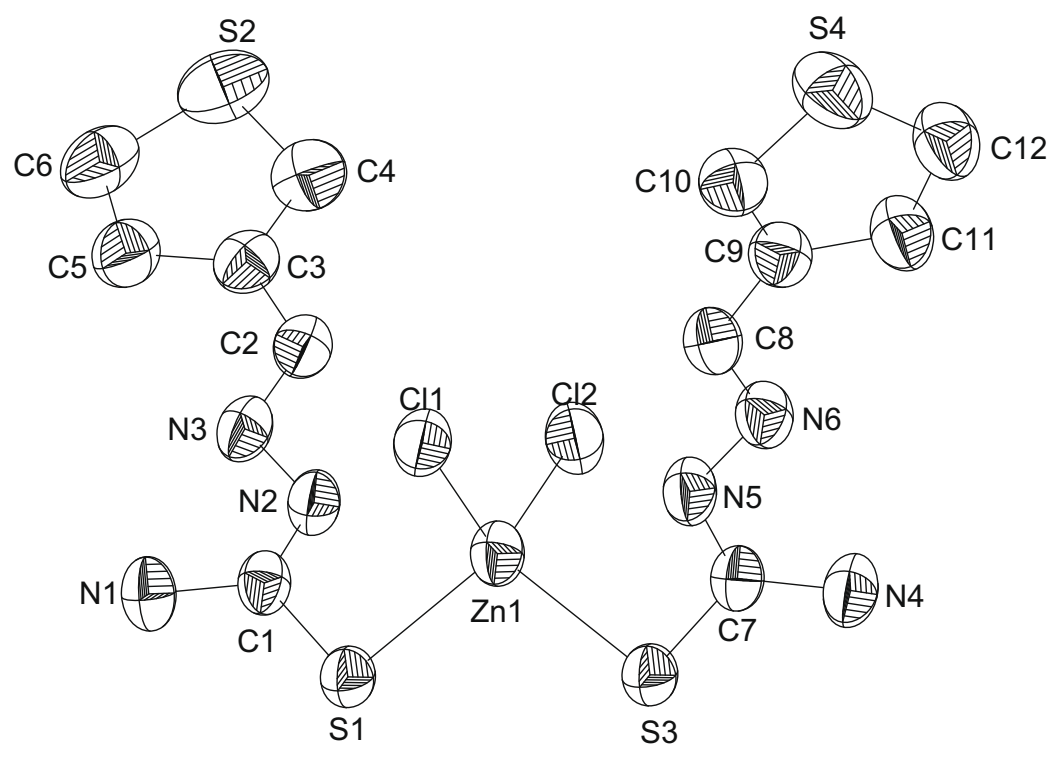

Fig. 2. ORTEP view (50\% displacement ellipsoid) and numbering scheme of $\left.\left[\mathrm{ZnCl}_{2}(3 T T S C H)\right)_{2}\right]$. 
suspended in sterile $\mathrm{NaCl}(0.15 \mathrm{M})$ were inoculated on the different Petri plates using the multipoint inoculator (AQS, England). After incubation for $24 \mathrm{~h}$ at $37^{\circ} \mathrm{C}$, the minimum inhibitory concentration (MICs $\mu \mathrm{g} / \mathrm{mL}$ ) of each compound against each bacterial strain was determined. The MIC is the lowest concentration leading to bacterial growth inhibition.

\subsubsection{Cytotoxic activity}

Cytotoxicity was evaluated at Institut de Chimie des Substances Naturelles, CNRS UPR 2301 (Gif sur Yvette, France) on MRC5 cells in DMSO at 10 and $1 \mu \mathrm{g} / \mathrm{mL}$ according to the procedure described by Moret et al. [16].

\section{Results and discussion}

As previously described, in the ligand, the sulfur atom S1 (see numbering scheme in Fig. 2) and the hydrazone nitrogen N3 are in $E$ position with respect to the $\mathrm{C} 1-\mathrm{N} 2$ bond [11].

\subsection{Crystal structure of $\left[\mathrm{ZnCl}_{2}\left(3 \mathrm{TSCH}_{2}\right]\right.$}

The main crystal parameters of both complexes are reported in Table 1 . The bond distances and angles are given in Table 2. The structure and the numbering scheme are given in Fig. 2. The struc-

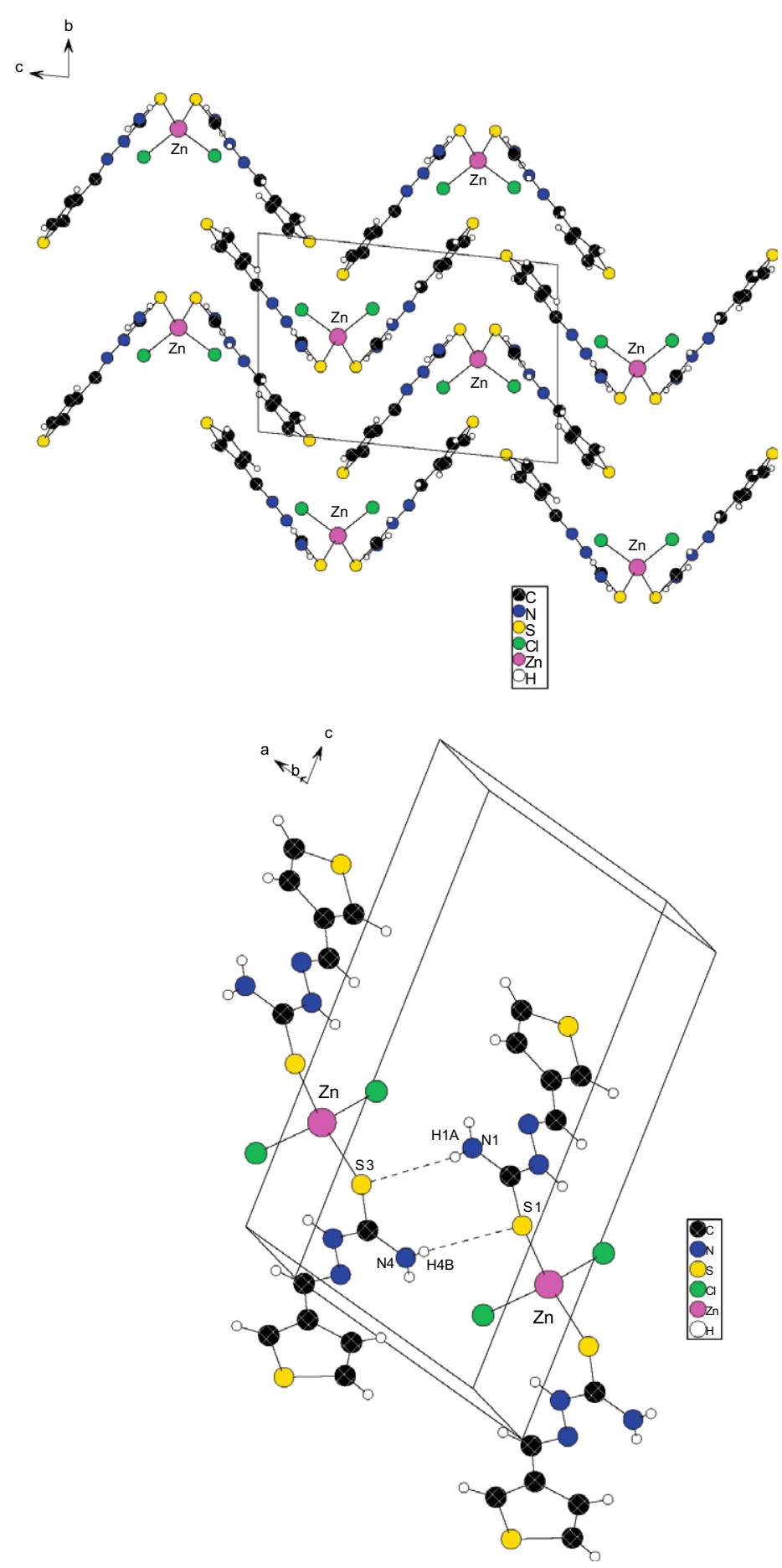

Fig. 3. Packing arrangement and hydrogen bonding for the zinc complex. 
ture consists in two $\left[\mathrm{ZnCl}_{2}(3 \mathrm{TTSCH})_{2}\right]$ independent identical molecules.

In each independent molecule, the zinc cation is tetrahedrically linked to two chloride ions and to the thione sulfur atom of each ligand. It is well known that thiosemicarbazones undergo tautomerism, leading to thione or thiol tautomer [17]. In this complex, the ligand remains in the same form than in the case of free ligand: thione tautomer. Each ligand is in $Z$ position relative to the $\mathrm{C} 1-\mathrm{N} 2$ and $\mathrm{C} 7-\mathrm{N} 5$ bonds respectively. During the coordination, there is a $180^{\circ}$ rotation around the $\mathrm{C} 1-\mathrm{N} 2$ bond (or C7-N5 bond) (see Fig. 1).

Each ligand is planar and all deviations are feeble though the thione sulfur atom presents a $0.1838 \AA, 0.1867 \AA$ and $0.7895 \AA$ deviation according to the three independent molecules in the ligand [11]. The angle between the planes of the two ligands is $78.255(30)^{\circ}$.

The bond length of the $\mathrm{C} 2-\mathrm{N} 3$ bond is $1.281 \AA$, that of N2-N3 is $1.392 \AA$, and these distances are typical of a $\mathrm{C}=\mathrm{N}$ double bond and of an $\mathrm{N}-\mathrm{N}$ single bond. In addition the bond length $\mathrm{C} 1-\mathrm{S} 1$ is $1.733 \AA$ which is between single and double bond $[11,18,19]$. In

Table 3

Selected bond lengths $(\AA)$ and angles $\left(^{\circ}\right)$ of an independent molecule for the cadmium complex.

\begin{tabular}{llll}
\hline Bond lengths & \multicolumn{3}{l}{ Bond angles } \\
\hline $\mathrm{C}(1)-\mathrm{N}(1)$ & $1.313(6)$ & $\mathrm{N}(1)-\mathrm{C}(1)-\mathrm{N}(2)$ & $118.7(4)$ \\
$\mathrm{C}(1)-\mathrm{N}(2)$ & $1.319(6)$ & $\mathrm{N}(1)-\mathrm{C}(1)-\mathrm{S}(1)$ & $120.0(4)$ \\
$\mathrm{C}(1)-\mathrm{S}(1)$ & $1.726(4)$ & $\mathrm{N}(2)-\mathrm{C}(1)-\mathrm{S}(1)$ & $121.3(3)$ \\
$\mathrm{C}(2)-\mathrm{N}(3)$ & $1.266(6)$ & $\mathrm{C}(1)-\mathrm{N}(2)-\mathrm{N}(3)$ & $118.3(3)$ \\
$\mathrm{N}(2)-\mathrm{N}(3)$ & $1.398(4)$ & $\mathrm{C}(2)-\mathrm{N}(3)-\mathrm{N}(2)$ & $114.7(4)$ \\
$\mathrm{S}(1)-\mathrm{Cd}(1)$ & $2.5473(12)$ & $\mathrm{C}(1)-\mathrm{S}(1)-\mathrm{Cd}(1)$ & $102.96(15)$ \\
$\mathrm{Br}(1)-\mathrm{Cd}(1)$ & $2.5992(7)$ & $\mathrm{S}(3)-\mathrm{Cd}(1)-\mathrm{S}(1)$ & $111.60(4)$ \\
$\mathrm{Br}(2)-\mathrm{Cd}(1)$ & $2.5815(7)$ & $\mathrm{S}(3)-\mathrm{Cd}(1)-\mathrm{Br}(2)$ & $110.50(3)$ \\
& & $\mathrm{S}(1)-\mathrm{Cd}(1)-\mathrm{Br}(2)$ & $107.69(3)$ \\
& & $\mathrm{S}(3)-\mathrm{Cd}(1)-\mathrm{Br}(1)$ & $108.46(3)$ \\
\hline
\end{tabular}

Table 4

Bond lengths $(\AA)$, angles $\left(^{\circ}\right)$ and position of intermolecular hydrogen bonds for ligand and $\mathrm{Ni}(\mathrm{II})$ complex.

\begin{tabular}{llll}
\hline Compound & Hydrogen bonds & Distance $(\AA)$ & Angle $\left(^{\circ}\right)$ \\
\hline$\left[\mathrm{ZnCl}_{2}(3 \mathrm{TTSCH})_{2}\right]$ & S1...H4B & $2.81(6)$ & $139(7)$ \\
& S3..H1A & $2.78(5)$ & $145(5)$ \\
{$\left[\mathrm{CdBr}_{2}(3 \mathrm{TTSCH})_{2}\right]$} & S1 ..H4C & $2.73(5)$ & $139(5)$ \\
& S3...H1B & $2.82(5)$ & $145(6)$ \\
\hline
\end{tabular}

the ligand this bond distance is $1.687 \AA$, while its length is $1.739 \AA$ in the case of [Ni(3TTSC $)_{2}$ ] obtained with the deprotonated thiol tautomer [11].These bond lengths are typical of a delocalization of the $\pi$ electrons along the bonds between $\mathrm{C} 1, \mathrm{~S} 1$ and $\mathrm{Zn}^{2+}$.

The crystal packing and the hydrogen bonds are shown in Fig. 3. In the unit cell, the molecules form zig-zag alternate chains. Two intermolecular hydrogen bonds occur between two adjacent $\left[\mathrm{ZnCl}_{2}(3 \mathrm{TTSCH})_{2}\right]$ molecules. Their distances as well as their angles, reported in Table 4, are consistent with those observed in similar compounds $[18,20]$.

\subsection{Crystal structure of $\left[\mathrm{CdBr}_{2}(3 \mathrm{TTSCH})_{2}\right]$}

The main crystal parameters are reported in Table 1 . The bond distances and angles are given in Table 3 and the structure and the numbering scheme is given in Fig. 4. In the complex $\left[\mathrm{CdBr}_{2}(3 \mathrm{TTSCH})_{2}\right]$, the cadmium cation is tetrahedrically linked to two bromine ions and the thione sulfur atom of two independent ligands. The two ligands are in $Z$ position relative to the $\mathrm{C} 1-\mathrm{N} 2$ and $\mathrm{C} 7-\mathrm{N} 5$ bonds respectively. The molecules of the two ligands are planar and the angle between the planes of the two ligands is $79.890(32)^{\circ}$. There are no significant deviations to the planes, like in the case of the $\mathrm{Zn}(\mathrm{II})$ compound.

The length of the $\mathrm{C} 2-\mathrm{N} 3$ bond is $1.266 \AA$, that of $\mathrm{N} 2-\mathrm{N} 3$ is $1.398 \AA$, and these distances are typical of a $\mathrm{C}=\mathrm{N}$ double bond and an $\mathrm{N}-\mathrm{N}$ single bond. In addition the bond length of the $\mathrm{C} 1-\mathrm{S} 1$ bond is $1.726 \AA$ which is between a single and a double bond as it has been already observed in the cases of the zinc complex and other similar species [18].

The crystal packing shows alternate molecules leading to wavy arrangement as shown in Fig. 5. The stability is governed by intermolecular hydrogen bonds between adjacent molecules (Table 4). The cadmium(II) ions are symmetrically located on the c edges $(z$ and $1-z$ coordinates with $z=0.73$ ).

\subsection{Structures of the complexes}

\subsubsection{Elemental analysis}

The elemental analysis of the ligand and its complexes are summarized in Table 5. A good harmony between the experimental and calculated values is observed and the molecular formulae of the complexes are: $\left[\mathrm{CdCl}_{2}(3 \mathrm{TTSCH})\right],\left[\mathrm{CdBr}_{2}(3 \mathrm{TTSCH})\right]$ (obtained at room temperature) and $\left[\mathrm{ZnCl}_{2}(3 \mathrm{TTSCH})_{2}\right],\left[\mathrm{CdBr}_{2}(3 \mathrm{TTSCH})_{2}\right]$ (prepared in ethanol refluxing conditions) respectively.

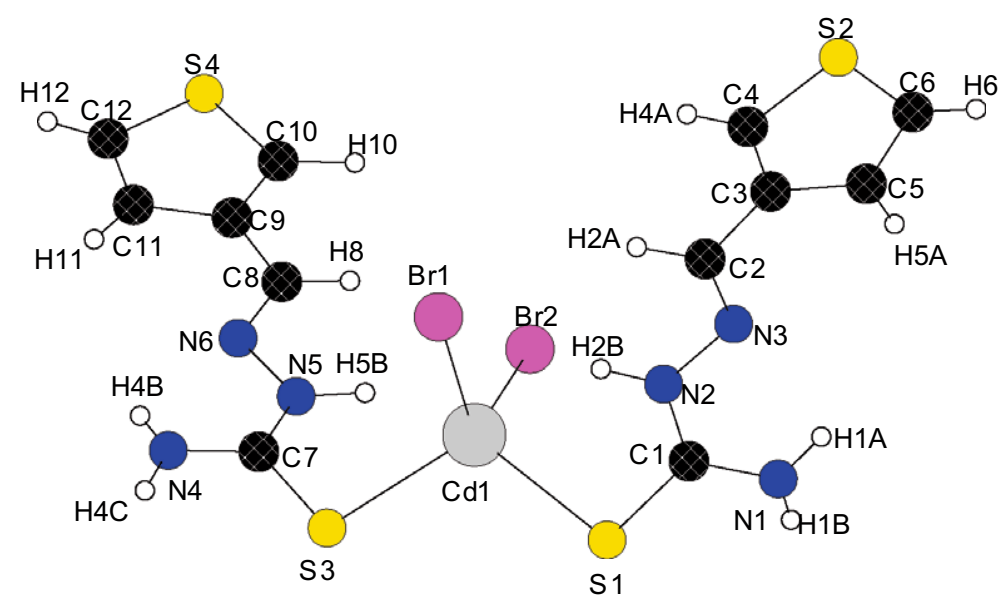

Fig. 4. Perspective view of complex and atom numbering of $\left[\mathrm{CdBr}_{2}\left(3 \mathrm{TTSCH}_{2}\right]\right.$. 


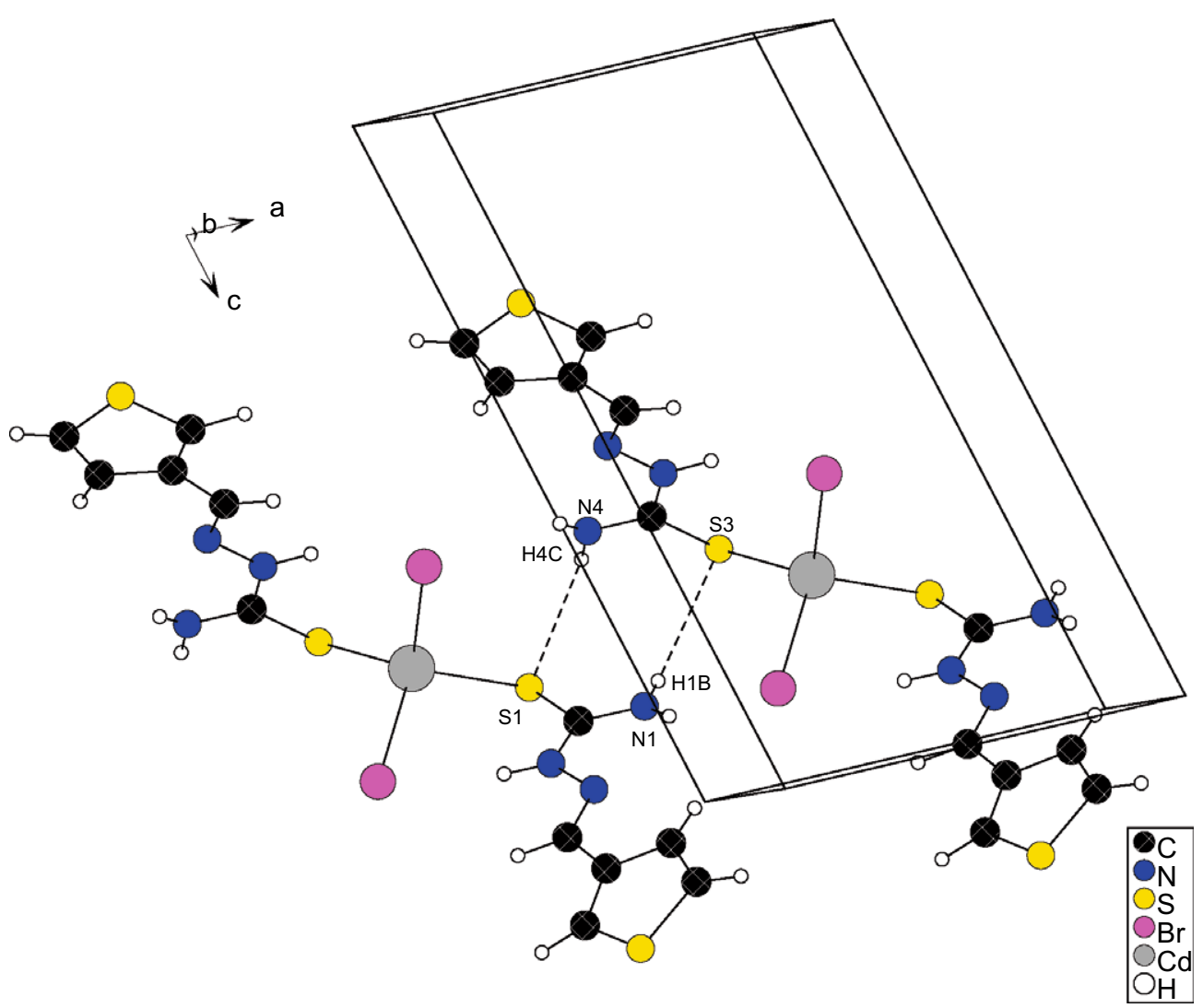

Fig. 5. Hydrogen bonds for the $\left[\mathrm{CdBr}_{2}\left(3 \mathrm{TTSCH}_{2}\right]\right.$.

Table 5

Analytical data.

\begin{tabular}{|c|c|c|c|c|c|c|}
\hline \multirow[t]{2}{*}{ Compound } & \multirow[t]{2}{*}{ Color } & \multirow[t]{2}{*}{ Yield (\%) } & \multirow[t]{2}{*}{$\mathrm{MP}\left({ }^{\circ} \mathrm{C}\right)$} & \multicolumn{3}{|c|}{ Elemental analysis found (calculated) } \\
\hline & & & & $\mathrm{C}(\%)$ & $\mathrm{H}(\%)$ & $\mathrm{N}(\%)$ \\
\hline 3TTSCH & Yellow & 93 & 165 & $38.98(38.87)$ & $3.81(3.77)$ & $22.68(22.67)$ \\
\hline$\left[\mathrm{ZnCl}_{2}(3 \mathrm{TTSCH})_{2}\right]$ & Brown & 59 & $198 \mathrm{~d}$ & $28.85(28.4)$ & $3.14(2.76)$ & $16.22(16.57)$ \\
\hline$\left[\mathrm{CdCl}_{2}(3 \mathrm{TTSCH})\right]$ & White & 78 & $267 d$ & $19.79(19.55)$ & $1.82(1.91)$ & $10.95(11.40)$ \\
\hline$\left[\mathrm{CdBr}_{2}(3 \mathrm{TTSCH})\right]$ & White & 74 & $177 \mathrm{~d}$ & $16.77^{\mathrm{a}}(15.79)$ & $1.85(1.32)$ & $9.22(9.21)$ \\
\hline$\left[\mathrm{CdBr}_{2}\left(3 \mathrm{TTSCH}_{2}\right]\right.$ & Orange & 62 & $212 \mathrm{~d}$ & $22.61(22.42)$ & $2.19(2.2)$ & $13.21(13.07)$ \\
\hline
\end{tabular}

$\mathrm{d}=$ Decomposition.

a Although the analysis data for "C" are somewhat unsatisfactory, ${ }^{1} \mathrm{H}$ NMR and IR spectroscopic data reasonably support the formula.

\subsubsection{Infrared spectra}

The main infrared vibration bands are reported in Table 6. Since the ligand contains a thioamide $-\mathrm{NH}-\mathrm{C}=\mathrm{S}$ functional group, it can exhibit the thione-thiol tautomerism [21]. The $v(\mathrm{~S}-\mathrm{H})$ band around $2570 \mathrm{~cm}^{-1}$ [11] is absent from IR spectra of the ligand but the $v(\mathrm{~N}-\mathrm{H})$ band at $3149 \mathrm{~cm}^{-1}$ is present, indicating that, in the solid state, the ligand remains as the thione tautomer. In addition, the spectrum of the ligand shows a strong band at $1603 \mathrm{~cm}^{-1}$ due to the $\mathrm{C}=\mathrm{N}$ stretching vibration [11].

In the case of the zinc complex, the $v\left(\mathrm{NH}_{2}\right)$ vibration band at $1600 \mathrm{~cm}^{-1}$, is slightly shifted to lower wavenumbers whereas $\mathrm{v}(\mathrm{N}-\mathrm{H})$ at $3157 \mathrm{~cm}^{-1}$ is shifted to higher values. The ring breath-

Table 6

Infrared data for the ligand and the complexes $\left(\mathrm{cm}^{-1}\right)$.

\begin{tabular}{|c|c|c|c|c|c|c|c|c|}
\hline Compound & $v\left(\mathrm{NH}_{2}\right)$ & $v(\mathrm{NH})$ & $v(\mathrm{C}=\mathrm{N})$ & $v(\mathrm{CS})$ & Ring breath & $v(\mathrm{~N}-\mathrm{N})$ & $v(\mathrm{M}-\mathrm{S})$ & $v(\mathrm{M}-\mathrm{N})$ \\
\hline 3TTSCH & 3408 & 3149 & 1603 & $\begin{array}{r}1165 \\
786\end{array}$ & 831 & 944 & - & - \\
\hline$\left[\mathrm{ZnCl}_{2}(3 \mathrm{TTSCH})_{2}\right]$ & 3405 & 3157 & 1600 & $\begin{array}{r}1169 \\
787\end{array}$ & 836 & 950 & 527 & - \\
\hline$\left[\mathrm{CdCl}_{2}(3 \mathrm{TTSCH})\right]$ & 3434 & 3198 & 1591 & $\begin{array}{r}1172 \\
779\end{array}$ & 834 & 944 & 540 & 430 \\
\hline$\left[\mathrm{CdBr}_{2}(3 \mathrm{TTSCH})\right]$ & 3395 & 3167 & 1598 & $\begin{array}{r}1161 \\
787\end{array}$ & 872 & 946 & 531 & 433 \\
\hline$\left[\mathrm{CdBr}_{2}(3 \mathrm{TTSCH})_{2}\right]$ & 3396 & 3168 & 1598 & $\begin{array}{r}1161 \\
787\end{array}$ & 833 & 946 & 526 & - \\
\hline
\end{tabular}

sh: Shoulder. 
ing vibration band is slightly changed when passing from the ligand to this complex $\left(831-836 \mathrm{~cm}^{-1}\right)$ [22]. In the mean time, the $\mathrm{v}(\mathrm{C}=\mathrm{N})$ vibration band is scarcely shifted to lower wavenumbers. The two bands corresponding to $v(\mathrm{C}=\mathrm{S})$, situated at 1169 and $787 \mathrm{~cm}^{-1}$ are significantly modified when compared to the ligand ones. In addition, the spectrum of the zinc complex shows the vibration band $v(\mathrm{M}-\mathrm{S})$ at $527 \mathrm{~cm}^{-1}$, which correspond to coordination bonds [23]. The same differences are observed when passing from the ligand to $\left[\mathrm{CdBr}_{2}\left(3 \mathrm{TTSCH}_{2}\right]\right.$.

In the spectra of the two other $\mathrm{Cd}(\mathrm{II})$ complexes, we find the same bands shifts than in the cases of $\left[\mathrm{ZnCl}_{2}(3 T T S C H)_{2}\right]$, and $\left[\mathrm{CdBr}_{2}\left(3 \mathrm{TTSCH}_{2}\right]\right.$. The spectra of $\left[\mathrm{CdCl}_{2}(3 \mathrm{TTSCH})\right]$ and $\left[\mathrm{CdBr}_{2}(3 \mathrm{TTSCH})\right]$ complexes show the presence of $v(\mathrm{M}-\mathrm{S})$ and, in addition, $v(\mathrm{M}-\mathrm{N})$ bands. Thus, in these complexes the coordination occurs through the sulfur and the nitrogen atoms of the imino moiety of the molecule. According, to these results, $\left[\mathrm{CdCl}_{2}(3 \mathrm{TTSCH})\right]$ and $\left[\mathrm{CdBr}_{2}(3 \mathrm{TTSCH})\right]$ are obtained with the neutral thione tautomer ligand.

\subsection{3. ${ }^{1} \mathrm{H}$ NMR spectra}

The ${ }^{1} \mathrm{H}$ NMR spectral data of the ligand and its complexes were recorded in DMSO- $\mathrm{D}_{6}$ with tetramethyl silane as an internal standard. The spectra of the ligand exhibits signals due to: three $-\mathrm{CH}$ heterocyclic protons, q, $\delta=7.59 \mathrm{ppm}(1 \mathrm{H}), \mathrm{dd}, \delta=7.72 \mathrm{ppm}(1 \mathrm{H})$, s, $\delta=8.08(1 \mathrm{H}) ;-\mathrm{NH}_{2}$ : dd., $\delta=7.90 \mathrm{ppm}(2 \mathrm{H}) ;-\mathrm{CH}=, \mathrm{s}, \delta=$ $8.22 \mathrm{ppm}(1 \mathrm{H}) ;-\mathrm{NH}, \mathrm{s}, \delta=11.40 \mathrm{ppm}(1 \mathrm{H})$.

In the case of $\left[\mathrm{ZnCl}_{2}(3 \mathrm{TTSCH})_{2}\right], \quad\left[\mathrm{CdCl}_{2}(3 \mathrm{TTSCH})\right], \quad\left[\mathrm{CdBr}_{2}-\right.$ $(3 \mathrm{TTSCH})]$ and $\left[\mathrm{CdBr}_{2}(3 \mathrm{TTSCH})_{2}\right]$ complexes the spectra are only slightly modified, with the same multiplicity of the signals and some slight changes in the chemical shifts with respect to the ligand. For example, in the case of $\left[\mathrm{CdBr}_{2}(3 \mathrm{TTSCH})_{2}\right]$ complex, the signals are: $-\mathrm{CH}$ heterocyclic protons: $\delta=7.57 \mathrm{ppm}(1 \mathrm{H})$, $\delta=7.70 \mathrm{ppm}(1 \mathrm{H}), \delta=8.06(1 \mathrm{H}) ;-\mathrm{NH}_{2}: \delta=7.90 \mathrm{ppm}(2 \mathrm{H})$; $-\mathrm{CH}=, \delta=8.18 \mathrm{ppm}(1 \mathrm{H}) ;-\mathrm{NH}, \delta=11.60 \mathrm{ppm}(1 \mathrm{H})$.

These ${ }^{1} \mathrm{H}$ NMR spectra are in agreement with the thione tautomer as indicated on the basis of infrared data.

\subsubsection{Thermal analysis}

In all cases, there is no signal in d.s.c. before the endothermic melting peak and the exotherms due to decomposition appear as soon as the compounds melt. The two cadmium(II) bromide complexes show different behavior. The complex $\left[\mathrm{CdBr}_{2}(3 \mathrm{TTSCH})\right]$ exhibits feeble endotherms starting from $147^{\circ} \mathrm{C}$ followed by a sharp endotherm at $177^{\circ} \mathrm{C}$ corresponding to its melting point. On the opposite side, $\left[\mathrm{CdBr}_{2}(3 \mathrm{TTSCH})_{2}\right]$ is very stable and there is only the endothermic melting point at $212{ }^{\circ} \mathrm{C}$ and, after immediately, the decomposition exothermic peaks.

\subsubsection{Proposed structures for the complexes}

The proposed structures of the $\left[\mathrm{CdCl}_{2}(3 \mathrm{TTSCH})\right],\left[\mathrm{CdBr}_{2}-\right.$ (3TTSCH)] complexes are given in Fig. 6. They were determined on the basis species of the crystal structure of the $\left[\mathrm{CdBr}_{2}\left(3 \mathrm{TTSCH}_{2}\right]\right.$ and from their spectroscopic data. In both com-

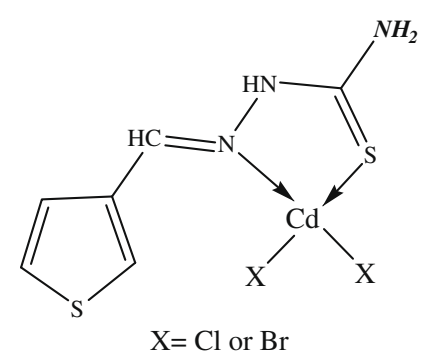

Fig. 6. Proposed structures of the cadmium(II) complexes. pounds, the coordination occurs through the sulfur atom and the $\mathrm{N}$ imino atom via the thione tautomer. In these two species, there is a tetrahedral arrangement around the $\mathrm{Cd}^{2+}$ ion.

Two complexes are obtained starting from cadmium(II) bromide. At room temperature, one ligand is bounded and at ethanol refluxing temperature a second ligand is then coordinated. The complex $\left[\mathrm{CdBr}_{2}(3 \mathrm{TTSCH})\right]$ is thermodynamically favored and precipitates instantaneously while the fixation of a second molecule of 3TTSCH is slow (kinetically unfavored) and needs higher temperature to obtain $\left[\mathrm{CdBr}_{2}(3 \mathrm{TTSCH})_{2}\right]$.

\subsection{Biological activities}

The complexes [Ni(3TTSC $)_{2}$ ], [Co(3TTSC $\left.)_{2}\right]$ and $\left[\mathrm{CuBr}_{2}(3 \mathrm{TTSCH})\right]$ were prepared as previously described [11].

In one hand, the antifungal results (Table 7) show that the cadmium complexes are the most active against all tested fungi with values higher than the reference amphotericin $\mathrm{B}$. The other complexes exhibit values in the same range of the ligand: between 13 and $21 \mathrm{~mm}$ on C. albicans and between 0 and $27 \mathrm{~mm}$ on C. glabrata. However, $\left[\mathrm{CuBr}_{2}(3 \mathrm{TTSCH})\right]$ revealed to be totally inefficient on the three fungi.

No antifungal activity was found for the $\mathrm{CoCl}_{2}, \mathrm{NiBr}_{2}$, and $\mathrm{ZnCl}_{2}$ salts on all tested fungi (data not shown). However, $\mathrm{CdCl}_{2}$ and $\mathrm{CdBr}_{2}$ provided the same values than their respective complexes explaining probably the activity of these latest. Nevertheless, for the three cadmium complexes the toxicity on MRC5 was negative at $1 \mu \mathrm{g} / \mathrm{mL}$ and largely diminished (30\% or $100 \%$ less active) at $10 \mu \mathrm{g} / \mathrm{mL}$ in comparison to the values obtained for the salts. This have been already observed, that free ions are more toxic than their complexes, probably due to the decreased bioavaibility of the metal ion [24]. So, it could be thought that $\left[\mathrm{CdBr}_{2}(3 \mathrm{TTSCH})_{2}\right]$, $\left[\mathrm{CdBr}_{2}(3 \mathrm{TTSCH})\right]$ and $\left[\mathrm{CdCl}_{2}(3 \mathrm{TTSCH})\right]$ could be interesting as antifungal therapeutic especially on A. fumigatus with high values between 50 and $55 \mathrm{~mm}$. Moreover, to our knowledge, it is the first time that thiophenaldehyde thiosemicarbazone complexes are evaluated on this species which is very currently present in immunodepressive pathology (e.g. cystic fibrosis, HIV) and usually responsible of many kind of resistance. This activity could be explain because that highly lethal fungi employ chelator biosynthesis in order to acquire iron from the host [24].

In the other hand, the antibacterial activity of the ligand, salts and complexes has also been screened against various bacterial strains. Looking for the results, it is observed that the coordination of metal ions has a pronounced effect on the bacterial activity of the ligand. Conversely to the antifungal results, no antibacterial activity was observed for the ligand 3TTSCH against all bacterial strains tested. Among the complexes tested, cadmium(II) com-

Table 7

Antifungal activities of the ligand and complexes expressed as the diameter of the inhibition zone ( $\mathrm{mm})$.

\begin{tabular}{llll}
\hline Compound & Fungi & & \\
\cline { 2 - 4 } & $\begin{array}{l}\text { Candida } \\
\text { albicans }\end{array}$ & $\begin{array}{l}\text { Candida } \\
\text { glabrata }\end{array}$ & $\begin{array}{l}\text { Aspergillus } \\
\text { fumigatus }\end{array}$ \\
\hline $3 \mathrm{TTSCH}$ & 18 & 27 & 0 \\
{$\left[\mathrm{Ni}(3 \mathrm{TTSC})_{2}\right]$} & 21 & 0 & 0 \\
{$\left[\mathrm{ZnCl}{ }_{2}(3 \mathrm{TTSCH})_{2}\right]$} & 17 & 18 & 0 \\
{$\left[\mathrm{Co}(3 \mathrm{TTSC})_{2}\right]$} & 18 & 18 & 0 \\
{$[\mathrm{CuBr}(3 \mathrm{TTSC})]_{2}$} & 13 & 0 & 0 \\
{$\left[\mathrm{CuBr}_{2}(3 \mathrm{TTSCH})\right]$} & 0 & 0 & 0 \\
{$\left[{\mathrm{CuCl}(3 \mathrm{TSC})]_{2}}\right.$} & 18 & 35 & 0 \\
{$\left[\mathrm{CdBr}_{2}(3 \mathrm{TTSCH})_{2}\right]$} & 27 & 40 & 52 \\
{$\left[\mathrm{CdBr}_{2}(3 \mathrm{TTSCH})\right]$} & 25 & 40 & 50 \\
{$\left[\mathrm{CdCl}_{2}(3 \mathrm{TTSCH})\right]$} & 27 & 0 & 50 \\
$\mathrm{Amphotericin} \mathrm{B}$ & 30 & 25 & 30 \\
\hline
\end{tabular}


Table 8

Antimicrobial activity expressed $(\mu \mathrm{g} / \mathrm{mL})$ as MIC of complexes and ligand on the $21 \mathrm{~g}$ positive and negative bacteria strains $(\mathrm{LH}=3 \mathrm{TTSCH})$.

\begin{tabular}{|c|c|c|c|c|}
\hline Bacteria & 3TTSCH & {$\left[\mathrm{CdCl}_{2}(\mathrm{LH})\right]$} & {$\left[\mathrm{CdBr}_{2}(\mathrm{LH})_{2}\right]$} & {$\left[\mathrm{CdBr}_{2}(\mathrm{LH})\right]$} \\
\hline Acinetobacter baumannii $\mathrm{RCH}$ & $>100$ & 40 & 80 & 80 \\
\hline A. baumannii SAN008 & $>100$ & 40 & 80 & 80 \\
\hline A. baumannii 12 & $>100$ & 60 & 80 & 80 \\
\hline A. baumannii AYE & $>100$ & 40 & 50 & 60 \\
\hline A. baumannii CIP7034 & $>100$ & 60 & 80 & 80 \\
\hline A. baumannii CIP107292 & $>100$ & 40 & 50 & 60 \\
\hline A. baumannii CIP5377 & $>100$ & 40 & 80 & 80 \\
\hline Staphylococcus aureus ATCC25923 & $>100$ & 100 & $>100$ & 100 \\
\hline MRSA clinical isolate $0706 \mathrm{C} 0025$ & $>100$ & 60 & 80 & 80 \\
\hline MRSA clinical isolate 0702E0196 & $>100$ & $>100$ & $>100$ & $>100$ \\
\hline MSSA clinical isolate $0703 \mathrm{H} 0036$ & $>100$ & 10 & 20 & 20 \\
\hline MSSA clinical isolate $0701 \mathrm{A0095}$ & $>100$ & 20 & 20 & 30 \\
\hline Escherichia coli ATCC25922 & $>100$ & 100 & $>100$ & $>100$ \\
\hline E. coli clinical isolate $0705 \mathrm{~A} 0434$ & $>100$ & $>100$ & $>100$ & $>100$ \\
\hline Enterobacter cloacae clinical isolate $0705 \mathrm{~A} 1743$ & $>100$ & $>100$ & $>100$ & $>100$ \\
\hline Enterobacter aerogenes clinical isolate $0705 \mathrm{A0} 067$ & $>100$ & $>100$ & $>100$ & $>100$ \\
\hline Klebsiella oxytoca clinical isolate $0705 \mathrm{C} 0187$ & $>100$ & 60 & $>100$ & $>100$ \\
\hline Salmonella enteritidis 4 & $>100$ & 80 & $>100$ & $>100$ \\
\hline Pseudomonas aeruginosa ATCC27853 & $>100$ & $>100$ & $>100$ & $>100$ \\
\hline P. aeruginosa clinical isolate $0704 \mathrm{C} 0134$ & $>100$ & $>100$ & $>100$ & $>100$ \\
\hline P. aeruginosa clinical isolate $0703 \mathrm{C} 0259$ & $>100$ & $>100$ & $>100$ & $>100$ \\
\hline
\end{tabular}

plexes and their salts were the most active on bacterial strains tested (Table 8). As it is often described in the literature, no activity was found for $\left[\mathrm{Ni}(3 \mathrm{TTSC})_{2}\right]$ and $\left[\mathrm{ZnCl}_{2}(3 \mathrm{TTSCH})_{2}\right]$ complexes (data not shown) [24-26].

Although, some residual activities were found on Meticillin Resistant S. aureus (MRSA) and Meticillin Sensitive S. aureus (MSSA) strains for $\mathrm{Co}(\mathrm{II})$ and $\mathrm{Cu}(\mathrm{II})$ complexes, it seems obvious that again, the cadmium complexes exhibited the largest spectrum with significant values ranging from $10 \mu \mathrm{g} / \mathrm{mL}$ (MSSA strain 0703H0036) to $100 \mu \mathrm{g} / \mathrm{mL}$ (S. aureus clinical strain ATCC25923). However, all $P$. aeruginosa strains were resistant to all the compounds tested. Interestingly, it can be noticed a markedly activity of the cadmium complexes on all $A$. baumannii strains (MICs between 40 and $80 \mu \mathrm{g} /$ $\mathrm{mL}$ ). A. baumannii is involved in nosocomial infections associated with significant morbidity and mortality, especially in intensive care units (ICUs). This bacterium persists in medical environments and outbreaks in ICUs have often been attributed to transmission via ventilatory equipment and to patient-to-patient transmission by the health care staff. Thus, new antibacterial compounds used for equipment disinfection will allow to markedly reduce infections caused by $A$. baumannii in humans.

To conclude, we note that the ligand and its complexes exhibited important antifungal inhibition activity on yeast and A. fumigatus with a marked one for the cadmium complexes. These latest show also significant antibacterial activity especially against $A$. baumanii strains, thus, they could be a hope for being new antiseptics.

\section{Acknowledgements}

The author swish to thank Geneviève Aubert from the Institut de Chimie des Substances Naturelles, CNRS UPR 2301 (Gif sur Yvette, France) for performing the cytotoxic assays for all the tested compounds.

\section{Appendix A. Supplementary material}

Crystallographic data have been deposited with the CCDC (12 Union Road. Cambridge, CB2 IEZ, UK (fax: +44 1223 336033; email: deposit@ccdc.cam.ac.uk or at http://www.ccdc.cam.ac.uk), and are available on request quoting the deposition numbers CCDC 714283 and 714284 . Supplementary data associated with this arti- cle can be found, in the online version, at doi:10.1016/ j.jinorgbio.2009.11.012.

\section{References}

[1] S.B. Novakovic, G.A. Bogdanovic, V.M. Leovac, Polyhedron 25 (2006) 10961104.

[2] E.L. Torres, M.A. Mendiola, J.R. Procopio, M.T. Sevilla, E. Colacio, J.M. Moreno, I. Sobrados, Inorg. Chem. Acta 323 (2001) 130-138.

[3] K. Peariso, C.W. Goulding, S. Huang, R.G. Matthews, J.E. Penner-Hahn, J. Am. Chem. Soc. 120 (1998) 8410-8416

[4] E.B. Seena, M.R.P. Kurup, Spectrochim. Acta A 69 (2008) 726-732.

[5] D.G. Calatayud, E.L. Torres, M.A. Mendiola, Polyhedron 27 (2008) 2277-2284.

[6] I.C. Mendes, J.P. Moreira, N.L. Speziali, A.S. Mangrich, J.A. Takahashi, H. Beraldo, J. Braz. Chem. Soc. 17 (2006) 1571-1577.

[7] E.M. Jouad, G. Larcher, M. Allain, A. Riou, G.M. Bouet, M.A. Khan, X.D. Thanh, J. Inorg. Biochem. 86 (2001) 565-571.

[8] G. Ibrahim, M.A. Khan, P. Richomme, O. Benali-Ba, G. Bouet, Polyhedron 16 (1997) 3455-3461.

[9] I. Hall, C. Lee, G. Ibrahim, M.A. Khan, G. Bouet, Appl. Organomet. Chem. 11 (1997).

[10] E.M. Jouad, X.D. Thanh, G. Bouet, N. Ménard, M.A. Khan, Biol. Rhythm Res. 33 (2002) 513.

11] K. Alomar, M.A. Khan, M. Allain, G. Bouet, Polyhedron 28 (2009) 1273-1281.

[12] G.M. Sheldrick, SHELX97 - Program for Crystal Structure Analysis (Release 972), University of Göttingen, 1998.

[13] D.X. West, J.K. Swearingen, J. Valdés-Martínez, S. Hernández-Ortega, A.K. El Sawaf, F. van Meurs, A. Castiñeiras, I. Garcia, E. Bermejo, Polyhedron 18 (1999) 2919-2929.

[14] J. Garcia-Tojal, A. Garcia-Orad, J.L. Serra, J.L. Pizarro, L. Lezama, M.I. Arriortua, T. Rojo, J. Inorg. Biochem. 75 (1999) 45-54.

[15] A.L. Barry, S.D. Brown, J. Clin. Microbiol. 34 (1966) 2154-2157.

[16] V. Moret, Y. Laras, T. Cresteil, G. Aubert, D.Q. Ping, C. Di, M. Barthélémy-Requin, C. Béclin, V. Peyrot, D. Allegro, A. Rolland, F. De Angelis, E. Gatti, P. Pierre, L Pasquini, E. Petrucci, U. Testa, J.-L. Kraus, Eur. J. Med. Chem. 44 (2009) 558 567.

[17] E.G. Akgemci, H. Bingol, T. Atalay, M. Ersoz, Electrochim. Acta 53 (2007) 673679.

[18] E. Bermejo, A. Castineiras, L.M. Fostiak, I.G. Santos, J.K. Swearingen, D.X. West, Polyhedron 23 (2004) 2303-2313.

[19] T.S. Lobana, P. Kumari, M. Zeller, R.J. Butcher, Inorg. Chem. Commun. 11 (2008) 972-974.

[20] E.M. Jouad, M. Allain, M.A. Khan, G.M. Bouet, J. Mol. Struct. 604 (2002) 205209.

[21] Y.-P. Tian, C.-Y. Duan, C.-Y. Zhao, X.-Z. You, T.C.W. Mak, Z.-Y. Zhang, Inorg. Chem. 36 (1997) 1247-1252.

[22] S. Gronowitz, A.R. Katritsky, R.E. Reavill, J. Chem. Soc. (1963) 3881-3882.

[23] J.R. Ferraro, Low-Frequency Vibrations of Inorganic and Coordination Compounds, Plenum Press, New-York, 1971

[24] N.J.S. Costa, C.R. Bombardieri, J.S. Kuribayashi, M.M. De Camargo, L.H. Andrade, E. Kagohara, B.P. Esposito, Chem. Biodiversity 5 (2008) 2156-2159.

[25] E. Bermejo, R. Carballo, A. Castineiras, R. Dominguez, A.E. Liberta, C. MaichleMössmer, M.M. Salberg, D.X. West, Eur. J. Inorg. Chem. (1999) 965-973.

[26] A.D. Bansod, R.G. Mahale, A.S. Aswar, Russ. J. Inorg. Chem. 52 (2007) 879-883. 